\title{
Література:
}

1. Вінграновський М. С. Атомні прелюдии: поезії / вступ. ст. Б. Буряка. Київ: Рад. письменник, 1962.118 с.

2. Вінграновський М. С. На срібнім березі: поезії. Київ: Молодь, 1978. $78 \mathrm{c}$.

3. Вінграновський М. С. Київ: поезії. Київ: Дніпро, 1982. 156 с.

4. Вінграновський М. С. Цю жінку я люблю: лірика. Київ: Дніпро, 1990. 206 c.

5. Вінграновський М. С. Любове, ні! не прощавай!: вибр. лірика. Київ: Укр. письменник, 1996. 149 с.

6. Дідула Р. Він гранив слово рідне : творчий спадок М. Вінграновського. Літ. Україна. 2006. 23 берез. С. 1-7.

7. Салига Т. М. Вінграновський. Київ: Рад. письменник, 1989. 156 с.

8. Старовойт Л. Мотиви і образи лірики Миколи Вінграновського. Питання літературознавства. Чернівці: Рута, 2007. Вип. 74. С. 74-81.

9. Талалай Л. Ілюзія добра і щастя : роздуми над поезією Миколи Вінграновського. Березіль. 2004. № 7-8. С. 166-176.

10. Ткаченко А. Мистецтво слова. Вступ до літературознавства. Київ: Правда Ярославичів, 1998. 448 с.

DOI https://doi.org/10.30525/978-9934-26-039-1-60

\section{ЕКЗИСТЕНЦІЙНА САМОТНІСТЬ АДРЕСАНТА В ЕПІСТОЛЯРІЇ ВІНСТОНА ЧЕРЧИЛЛЯ}

\author{
Семенюк О. Б. \\ старший викладач кафедри романо-германських мов \\ Національної академії Служби безпеки України \\ м. Київ, Украӥна
}

Проблема екзистенційної самотності генія неодноразово досліджувалася у літературознавчих студіях (Н. Хамітов І. Денисюк, М. Ільницький, Н. Калениченко, О. Кривуляк, Колінько О. П.). Проте спосіб зображення самотності людини як ознаки людської екзистенції через призму вираження внутрішнього світу митця в епістолярній формі ще не достатньо вивчена.

Розмірковуючи над явищем самотності, екзистенціалісти намагалися довести, що єдиний засіб звільнення від самотності - це заглиблення в себе, у сутність свого буття і внутрішній світ людини. Дослідник 
Н. Хамітов інтерпретує екзистенційну самотність як феномен, що «виражає буття людини, яке наповнене стражданням в результаті відчуження від себе та роду, втрати й пошуку самототожності» $[4$, с. 4]. Проте, «екзистенціал» самотності інколи виражається не лише у песимістичних замальовках, він стає для письменника стимулом творчості. Проблема людської самотності, найповніше осмислена філософією екзистенціалізму Альбера Камю та Фрідріха Ніцше і може мати позитивний відтінок. тому що «самотність $є$ однією із обов'язкових сходинок на шляху до самопізнання» $[2$, с. 226].

Феномен екзистенційної самотності знайшов своє відображення не лише у прозі романтиків та письменників-модерністів, він був притаманний митцям, які втілили філософію екзистенціалізму в епістолярній формі. Трактуючи категорію авторської самотності як певну константу епістолярного жанру, ряд дослідників вважають, що відчуття самотності $\epsilon$ іманентним стимулом до написання листа як тексту [2, с. 209].

Феномен екзистенційної самотності митця в епістолярії Вінстона Черчилля - це відображення внутрішньої боротьби адресанта із його депресивними думками, зовнішнім середовищем, в якому розвивалася особистість самотнього лідера. Почуття самотності переслідувало Вінстона Черчилля із дитинства, у період навчання у приватному пансіонаті батьки рідко його навідували, проте це допомогло адресанту усвідомити власне «я», розвинути самокритику і самоаналіз. В періоди військових походів Вінстона Черчилля листи до дружини і матері стали єдиним зв'язком із батьківщиною, у них вилилися і біль від розлуки, $\mathrm{i}$ туга, і страждання. Лист виступає фантомом нерозривності, джерелом сугестії, передаючи антагоністичні думки адресанта i служить визначальним ідентифікатором індивідуального стилю Вінстона Черчилля. Самотність характеризує не лише внутрішнім душевний стан письменника, вона ототожнюється із хворобою Черчилля: серцевими нападами, психологічними травмами i депресією - усе це інтерпретується автором символічним образом «black dog», «чорного пса», який його часто переслідував.

Вперше адресант згадує про свою хворобу (депресію) у листі до Клементини 1911 року: «Alice interested me in her talk about her doctor in Germany who completely cured her depression. I think this man might be useful to me - if my black dog returns. He seems quite away from me now - it is such a relief. All the colours come back into the picture. Brightest of all your dear face - my Darling...». («Мене зацікавила розповідь Аліси про лікаря у Німеччині, котрий повністю вилікував іiї від депресії. Я думаю, що цей чоловік міг би мені стати в нагоді - якщо мій «чорний пес» повернеться. 
Зараз він здається мені зовсім далеко - це таке полегшення. Всі кольори повертаються. Найяскравіше - твоє миле обличчя, моя кохана».) [3, с. 53] (тут і далі переклад наш - О. Семенюк).

Але Черчилль довго і невтомно працював, щоб утримати свого «чорного пса на повідку» і не дати хворобі перемогти його, він був спроможний здійснювати великі справи. В іншому листі до дружини (від 28 січня 1916 року) автор зізнається: «Yои must not suppose that any of my depressions here have any relation to those terrible and reasonless depressions $w[$ hic] h frighten me sometimes. I sorrow only for real things, for g[rea]t enterprises cast away needlessly-wantonly-for not having the power w[hic]h I c[oul]d use better than any other living Englishman to determine the war policy of Britain. It is painful at times; but it is bearable always. Otherwise my spirits are surprisingly good». («Ви не повинні припускати, що будь-яка із моїх депресій тут має відношення до тих жахливих $\mathrm{i}$ безпідставних депресій, які іноді лякають мене. Я сумую лише за реальними речами, за великими підприємствами, які відкинуті без потреби - безглуздо - за тим, що я не маю тієї влади, яку зміг би краще застосувати, аніж будь-який інший існуючий англієць, щоб визначити воєнну політику Великобританії. Іноді це дуже боляче, але завжди терпимо. В іншому разі, настрій у мене, напрочуд, гарний») [1, с. 123].

Відчуття самотності, порожнечі, апатії, часті зміни настрою, переходи від депресивних думок до раптового приливу енергії і бадьорості - це все знаходило відгук не лише у душевних поривах адресанта, але чітко відображалося у композиції листа та індивідуальній стильовій парадигмі - оригінальній системі авторської ідентичності - символізмі і глибокому психологізмі, самоаналізі та рецепції у різних іï проявах. Адресант страждав від самотності та депресії, але ніколи не визнавав самотність як недуг, навпаки, ці періоди завершувалися підйомами у його творчості, оскільки сили письменнику додавали листовні розмови із адресатом. "I am now deeply immersed in the very small things which fall to my lot. I do all I can with zest, but I must confess to many spells of emptiness \& despondency at the narrow sphere in which I work \& severely restricted horizon...This is disorganized sort of letter, but you must make allowances! My strong natural vitality will carry me along». («Я надто глибоко занурився у дрібниці, які випали на мою долю. Я роблю все, що можу, із завзяттям, але маю зізнатися у частих періодах порожнечі і відчутті зневіри у вузькій сфері, в якій я працюю, і суворо обмеженому кругозорі... Цей лист трохи хаотичний, але ти повинна взяти це до уваги. Моя сильна природня життєздатність додасть мені сили») [3, с. 148]. 
Листи В. Черчилля, написані в окопах Західного фронту та під час його відставки із посади першого лорда Адміралтейства в 1915 році після провалу кампанії Дарданелл, передають песимістичні настрої, оскільки автор переживав найболючіші кризові моменти приватного і соціального життя. Адресант глибоко відчував політичну ганьбу та докори сумління, від яких він ніколи не зміг би оговтатися без підтримки своєї дружини. Песимістичні настрої досягають апогею напередодні вирішальної битви i у написаному в цей день листі домінують чорні тони, навіть письменнику вважаються символічні образи, зокрема темні тіні.

У липні 1915 року Черчилль написав прощальний лист своїй дружині 3 преамбулою: «його слід надіслати на випадок моєї смерті». Він благав дружину: «Do not grieve for me too much <...> Death is only an incident, and not the most important that happens to us in this state of being. On the whole, especially since I met you, my darling one, I have been happy and you have taught me how noble a woman's heart can be <...>. Meanwhile look forward, feel free, rejoice in life, cherish the children, guard my memory. God bless you, goodbye, W». («Не сумуй за мною дуже сильно <...> Смерть це лише інцидент, i не найголовніше, що трапляється із нами у такому стані. Загалом, особливо з того часу, як я познайомився із тобою, моя кохана, я почуваюся щасливим, і ти навчила мене, яким шляхетним може бути жіноче серце <...> . Тим часом дивись вперед, почувайся вільною, радій життю, плекай дітей, бережи мою пам'ять. Нехай Бог благословляє тебе. Прощавай, В.») [3, с. 111].

Концепція смерті - це не перехід в інший світ, на думку адресанта, смерть завжди екзистенційна, тобто це звичайний випадок, який трапляється із кожним. Сутність буття - це приносити користь людству. «I shall do my best to play a good game» («Я зроблю все можливе, щоб зіграти гарну гру».) [3, с. 781], - стверджує своє життєво кредо письменник у листі до матері.

Отже, феномен екзистенціної самотності проявляється в епістолярних діалогах Вінстона Черчилля у двох вимірах: внутрішньому психологізмі і драматизмі адресанта у формі образів-символів та у філософськоконцептуальному наповненні епістолярного наративу ідеями екзистенціалізму.

\section{Література:}

1. Attenborough W. Diagnosing Churchill: Bipolar or «Prey to Nerves»? Jefferson: McFarland, N.C. 2019. 275 p. 
2. Ільків А. В. Інтимний дискурс письменницького епістолярію другої половини XIX- початку XX століть: монографія / за ред. C.I. Хороба. Івано-Франківськ: Фоліант, 2006. 372 с.

3. Soames M. Speaking for themselves: The Personal letters of Winston and Clementine Churchill / Edit. M. Soames. London: Doubleday, 1998. $702 \mathrm{p}$.

4. Хамітов Н.В. Самотність як феномен людського буття: автореф. дис...доктора філос. наук: 09.00.04 «Естетика»; НАН України, Інститут філософ. ім. Сковороди. К.,1998. 34 с. 